\title{
Identifikasi Bakteri Asam Laktat Isolat 18A Secara Fenotipik
}

\section{(LACTIC ACID BACTERIA ISOLATE 18A PHENOTYPIC IDENTIFICATION)}

\author{
I Wayan Suardana ${ }^{1}$, Hendro Sukoco ${ }^{2}$, Nyoman Semadi Antara ${ }^{3}$ \\ ${ }^{1}$ Laboratorium Kesehatan Masyarakat Veteriner, \\ ${ }^{2}$ Mahasiswa Program Pendidikan Dokter Hewan, Fakultas Kedokteran Hewan, Denpasar, \\ ${ }^{3}$ Laboratorium Bioindustri dan Lingkungan, Fakultas Teknologi Pertanian, Universitas Udayana, \\ Bukit Jimbaran, Bali, "E-mail: iwayansuardana22@yahoo.com
}

\begin{abstract}
ABSTRAK
Bakteri Asam Laktat (BAL) memiliki kemampuan dalam menghambat pertumbuhan bakteri patogen, salah satunya adalah BAL isolat 18A. Penelitian ini bertujuan untuk menentukan spesies BAL dari isolat 18A dengan uji konvensional dan uji KIT API $50 \mathrm{CH}$. Penelitian ini merupakan penelitian observasional deskriptif, dengan objek penelitian berupa bakteri asam laktat isolat 18A asal kolon sapi bali. BAL isolat 18A direkulturisasi, dengan penumbuhan pada media MRS, uji katalase, dan pewarnaan Gram. Uji identifikasi isolat dengan uji produksi gas $\mathrm{CO}_{2}$, uji pertumbuhan pada $\mathrm{NaCL} 15 \%$, uji pertumbuhan pada Suhu $10^{\circ} \mathrm{C}$, dan uji pertumbuhan pada $\mathrm{pH} 9,6$. Konfirmasi isolat juga dilakukan dengan uji kit API (Standard Analytical Profile Index) $50 \mathrm{CH}$. Hasil rekulturisasi menunjukkan isolate 18A mampu tumbuh dengan baik pada media MRS broth, bersifat katalase negatif, Gram positif, berbentuk bulat, dan berantai. Hasil identifikasi mengindikasikan bahwa isolat $18 \mathrm{~A}$ bersifat homofermentatif, mampu tumbuh pada suhu $10^{\circ} \mathrm{C}$, dan tidak tumbuh pada $\mathrm{pH} 9,6$. Uji fermentasi dengan menggunakan perangkat kit API $50 \mathrm{CH}$, menunjukkan bahwa isolat $18 \mathrm{~A}$ mampu mendegradasi 15 komponen gula, yaitu komponen gula no : 5, 10, 11, 12, 13, 22, 24, 25, 26, 27, 28, 29, 30, 31, dan 39. Hasil identifikasi secara konvensional dapat disimpulkan bahwa isolate 18A merupakan genus Lactococcus. Dan berdasarkan uji konfirmasi menggunakan Kit API 50 CHL disimpulkan bahwa isolat 18A merupakan bakteri Lactococcus Lactis ssp lactis 1.
\end{abstract}

Kata kunci: bakteri asam laktat; isolat 18A; uji konvensional; Kit API $50 \mathrm{CH}$.

\begin{abstract}
Lactic Acid Bacteria (LAB) is a bacterium that has an ability to inhibit a pathogenic bacteria growth, including isolates $18 \mathrm{~A}$. The aim of this study is to determine the species of LAB isolates $18 \mathrm{~A}$ by conventional tests and API $50 \mathrm{CH}$ test. This study was a descriptive observational study, with lactic acid bacteria isolates $18 \mathrm{~A}$ were obtained from bali cattle's colon as an object. LAB isolates $18 \mathrm{~A}$ were re-cultured on MRS media, catalase test, and Gram staining. Identification test were performed by $\mathrm{CO} 2$ production test, growth in the presence of $15 \% \mathrm{NaCl}$, growth at $10^{\circ} \mathrm{C}$, and growth at $\mathrm{pH} 9.6$. Confirmation test were performed using API $50 \mathrm{CH}$ (Standard Analytical Profile Index). The results indicated that LAB isolate $18 \mathrm{~A}$ were able to grow well on MRS broth media, catalase-negative, Gram-positive, and spherical-chain in shape. Identification test revealed that the bacteria is homofermentative, were able to grow at $10^{\circ} \mathrm{C}$, and do not grow at $\mathrm{pH} 9.6$. Fermentation test using API $50 \mathrm{CH}$ showed that LAB isolates $18 \mathrm{~A}$ were able to degrade 15 sugar components, consist of no: 5,10 , $11,12,13,22,24,25,26,27,28,29,30,31$, and 39. Based on conventional identification results, it can be concluded that BAL isolates $18 \mathrm{~A}$ is a Lactococcus. In addition, the result of API $50 \mathrm{CHL}$ test showed that BAL isolates $18 \mathrm{~A}$ is a Lactococcus lactis ssp lactis 1.
\end{abstract}

Keywords: lactic acid bacteria; isolates $18 \mathrm{~A}$; conventional test; API 50CH test

\section{PENDAHULUAN}

$\begin{array}{rccr}\text { Bakteri } & \begin{array}{c}\text { Asam } \\ \text { jenis }\end{array} & \begin{array}{c}\text { Laktat } \\ \text { bakteri }\end{array} & \text { (BAL) } \\ \text { yang }\end{array}$
menguntungkan, karena berperan terhadap dunia pangan dan kesehatan. BAL termasuk ke dalam kelompok bakteri yang memenuhi status Generally Recognized As
Safe (GRAS) bagi manusia (Surono, 2004). Dalam dunia industri pangan, bakteri asam laktat pada produk fermentasi mempunyai peranan untuk memperbaiki cita rasa produk pangan (Leisner et al., 2001; Amiza et al., 2006). Selain itu BAL juga mempunyai efek pengawetan pada 
produk yang dihasilkannya, sehingga banyak digunakan sebagai bahan pengawet alami (biopreservatif) (Widiasih, 2008).

Selain itu, bakteri asam laktat juga banyak dimanfaatkan sebagai salah satu bahan pangan fungsional berupa probiotik. Hal ini terkait dengan sifat antimikroba dan produksi seyawa mikrobisidal oleh bakteri asam laktat, yang memiliki peran dalam membunuh atau menghambat perlekatan bakteri patogen pada saluran cerna (Ljungh and Wadstrom, 2006). Bakteri asam laktat memiliki akivitas antimikroba karena dapat menghasilkan bakteriosin yang mampu menghambat pertumbuhan dan mematikan bakteri patogen (Zacharof dan Lovitt, 2012). Beberapa penelitian telah membuktikan aktivitas antimikroba bakteriosin terhadap bakteri Gram positif dan negatif yang dihasilkan oleh bakteri asam laktat hasil isolasi dari daging dan olahan daging (Bromberg et al, 2004), ikan (Vijayabaskar and Somasundaram, 2008), keju dan yogurt (Yang et al., 2012 ; Suarsana, 2011).

Sapi bali sebagai salah satu ternak lokal memiliki ciri genetik yang khas yaitu hidupnya sederhana atau dapat dengan mudah beradaptasi dengan lingkungan yang kurang menguntungkan sehingga disebut sebagai sapi perintis atau sapi pelopor (Sari, et a1., 2016; Saptayanti, 2015). Penelitian yang dilakukan oleh Lindawati dan Suardana (2014) telah berhasil mengisolasi bakteri asam laktat asal kolon sapi bali, dengan melakukan serangkaian uji yakni penanaman pada media MRS, uji katalase, pewarnaan Gram dan uji seleksi aktivitas antimikroba. Salah satu isolat tersebut adalah isolat 18A. Berdasarkan hasil uji aktivitas antimikroba, menunjukkan bahwa terbentuk killing zone di sekitar tempat pertumbuhan bakteri indikator Staphylococcus aureus dan Eschericia coli yang diuji pada isolat 18A (Lindawati dan Suardana, 2014).
Dengan memperhatikan kemampuan isolat $18 \mathrm{~A}$ dalam menghambat pertumbuhan bakteri patogen, maka isolat 18A potensial untuk diidentifikasi lebih lanjut untuk mengetahui spesies dari isolat yang dimaksud. Identifikasi bakteri asam laktat dapat dilakukan berdasarkan sifat fenotipik dan kemampuan dalam memfermentasi berbagai macam karbohidrat (Nurhayati et al., 2011 ; Surono, 2004). Identifikasi fenotipik didasarkan pada hasil pengamatan morfologi, yaitu bentuk sel, pewarnaan Gram, uji katalase, dan fisiologi. Identifikasi untuk mengetahui sifat biokimia bakteri asam laktat dalam memfermentasi berbagai jenis karbohidrat dapat dilakukan dengan menggunakan uji tes Kit API 50 CHL.

\section{METODE PENELITIAN}

Objek yang digunakan dalam penelitian ini adalah bakteri asam laktat isolat 18A asal kolon sapi bali yang disimpan dalam larutan gliserol 30\% pada suhu $-20^{\circ} \mathrm{C}$. Isolat BAL $18 \mathrm{~A}$ kemudian dithawing pada suhu $4^{\circ} \mathrm{C}$.

\section{Kultivasi Isolat 18A}

\section{Penanaman Pada Media MRS Broth}

Isolat $18 \mathrm{~A}$ diambil dari stock culture pada suhu $-20^{\circ} \mathrm{C}$, kemudian ditumbuhkan pada media MRS broth. Kemudian, media MRS broth diinkubasikan pada kondisi anaerob dengan menambahkan dua sachet $\left(3600 \mathrm{ml} \mathrm{H} \mathrm{H}_{2}\right.$ dan $700 \mathrm{ml} \mathrm{CO}_{2}$ ) gas generating kit ke dalam tabung anaerob untuk selanjutnya diinkubasi pada suhu $37^{\circ} \mathrm{C}$ selama 24-48 jam (Suardana.,et al. 2007).

\section{Uji Katalase}

Isolat diambil dari MRS broth dengan menggunakan micropipet. Setelah itu teteskan ke dalam cawan petri, dan tambahkan $\mathrm{H}_{2} \mathrm{O}_{2} 10 \%$. Kemudian amati segera adanya gelembung gas yang terbentuk pada preparat, bila terdapat gelembung gas bakteri tersebut katalase positif, dan apabila tidak terbentuk 
gelembung gas bakteri tersebut katalase negatif.

\section{Pewarnaan Gram}

Isolat dari MRS broth diambil dengan menggunakan ose lalu disebarkan setipis mungkin di atas kaca objek kemudian dilakukan fiksasi. Kristal violet sebanyak 1 tetes ditambahkan ke permukaan preparat yang terdapat lapisan bakteri tersebut dan didiamkan selama satu menit. Setelah satu menit, preparat dibilas dengan air sampai zat warna luntur. Preparat dikeringkan di atas api spiritus. Setelah kering, larutan lugol sebanyak satu tetes ditambahkan ke permukaan preparat tersebut dan didiamkan selama satu menit. Setelah satu menit, preparat dibilas dengan air. Preparat dibilas dengan alkohol 96\% sampai semua zat warna luntur kemudian dicuci dengan air. Preparat dikeringkan di atas api spiritus. Setelah kering, safranin sebanyak satu tetes ditambahkan ke permukaan preparat dan didiamkan selama 45 detik. Preparat dicuci dengan air dan dikeringkan. Preparat diamati menggunakan mikroskop dengan perbesaran 1000x (Pratita dan Putra, 2012).

\section{Uji identifikasi isolat $18 \mathrm{~A}$}

Uji Identifikasi Isolat 18A berdasarkan metode Holzapfel dan Shilinger, (1992) seperti yang disitasi oleh Widodo (2003), yang meliputi uji produksi gas $\mathrm{CO} 2$, pertumbuhan pada suhu $10^{\circ} \mathrm{C}$, dan $\mathrm{pH} 9,6$. Hasil uji selanjutnya disesuaikan dengan kunci determinasi.

\section{Uji produksi gas $\mathrm{CO}_{2}$}

Uji Gas $\mathrm{CO}_{2}$ dilakukan dengan cara mencelupkan ose yang sudah dipanasi ke dalam tabung yang berisi media MRS broth dan isolat BAL. Kemudian amati segera setelah pencelupan ose, adanya gelembung gas yang terbentuk. Apabila bakteri asam laktat yang diuji menghasilkan gelembung gas pada preparat, bakteri asam laktat tersebut dinyatakan sebagai heterofermentatif, sedangkan isolat yang tidak menghasilkan gelembung gas disebut homofermentatif.

\section{Uji pertumbuhan pada suhu $10^{\circ} \mathrm{C}$.}

Tanam isolat BAL pada media MRS broth, kemudian masukkan ke dalam lemari pendingin dengan suhu $10^{\circ} \mathrm{C}$ selama 24-48 jam dalam kondisi anaerob. Dan amati kekeruhannya. Hasil positif atau adanya pertumbuhan ditunjukkan dengan terbentuknya kekeruhan dan mempunyai nilai optical density lebih dari 0,4, sedangkan apabila nilai optical density dibawah 0,4 , maka bakteri tersebut tidak tumbuh (Campbell, 2011).

\section{Uji pertumbuhan pada $\mathrm{pH} \mathbf{9 , 6}$}

Isolat BAL diinokulasi pada media MRS broth yang telah diatur $\mathrm{pH}$ dengan cara menambahakan $\mathrm{NaOH}$ 1\% sampai $\mathrm{pH}$ mencapai 9,6 kemudian inkubasikan pada suhu $37^{\circ} \mathrm{C}$ dalam kondisi anerob. Setelah diinkubasikan selama 24-48 jam dilakukan pengukuran OD (Optical Density) dengan menggunakan alat spectrophotometer. Hasil positif ditandai dengan terbentuknya kekeruhan pada media, dan mempunyai nilai optical density lebih dari 0,4, sedangkan apabila nilai optical density dibawah 0,4, maka bakteri tersebut tidak tumbuh (Campbell, 2011)

\section{Konfirmasi bakteri asam laktat hasil identifikasi dengan uji Kit API 50 CHL.}

Isolat $18 \mathrm{~A}$ diambil dari stock culture pada suhu $-20^{\circ} \mathrm{C}$, kemudian ditumbuhkan pada media MRS broth. Biakan isolat umur 24 jam divortex 2000 rpm selama 10 menit (1ml), kemudian supernatannya dibuang. Setelah itu ditambah dengan saline steril $(1 \mathrm{ml})$ seperti volume semula, dan vortex $2000 \mathrm{rpm}$ selama 10 menit. Endapan yang didapat setelah supernatannya dibuang, ditambah saline \pm $0,5 \mathrm{ml}$ ( isolat siap digunakan). Perangkat API 50 CHL ditetesi dengan aquades steril pada setiap lubang 1 dasar plastik ( untuk membuat suasana lembab). Kemudian isi dengan API 50 CHL sesuai urutan nomernya (1-50). Tunggu sekitar lima menit, sambil tutup dengan plastik. Siapkan isolat yang akan diuji dengan cara menanam $100 \mathrm{ml}$ isolat yang telah disiapkan ke dalam media API 50 CHL 10 
ml ( CHL medium $10 \mathrm{ml}$ ) dan vortex. Tanam $100 \mu \mathrm{l}$ isolat yang telah tercampur dengan medium API 50 CHL setiap lubang dari perangkat kit (0-50) yang masing-masing mengandung jenis gula yang berbeda-beda. Inkubasikan pada $37^{\circ} \mathrm{C}$ dengan suasana anaerob dengan menambahkan anaerob gas kit dua sachet. Kemudian dibaca dalam 24 jam dan 48 jam., serta analisa menggunakan software APIWEB.

\section{HASIL DAN PEMBAHASAN}

\section{Hasil}

\section{Kultivasi Isolat 18A}

\section{Penanaman Pada Media MRS broth}

Isolat 18A mampu tumbuh dengan baik pada media MRS broth. Pertumbuhan ditandai dengan adanya kekeruhan pada media. Media MRS merupakan media selektif yang pada awalnya dikembangkan untuk menyediakan media pertumbuhan spesifik dari lactobacilus oleh de Man, Rogosa dan Sharpe, dan juga untuk mendukung pertumbuhan bakteri yang sulit tumbuh seperti $L$. brevis dan $L$. fermentum (de Man et al., 1960; Leroy dan Vuyst, 2001; Bujalance et al., 2006). Namun saat ini MRS telah digunakan secara luas untuk bakteri asam laktat secara umum seperti Lactobacillus, Pediococcus, Enterococcus, Bifidobacterium dan Leuconostoc. Kandungan amonium sitrat pada $\mathrm{pH}$ rendah dapat menghambat pertumbuhan sebagian mikroorganisme, tetapi kondisi tersebut memungkinkan pertumbuhan dari bakteri asam laktat. Dipotassium fosfat dan Sodium asetat merupakan senyawa dalam MRS yang berperan sebagai buffer untuk mempertahankan $\mathrm{pH}$ tetap rendah. Kandungan Tween 80 berfungsi untuk emulsifier. Mangan dan Magnesium sulfat merupakan sumber ion dan sulfat. Pepton dan ekstrak daging sapi menyediakan nitrogen, vitamin, mineral dan asam amino esensial untuk pertumbuhan. Ekstrak ragi merupakan sumber vitamin, khususnya Bkompleks. Dextrose adalah karbohidrat yang dapat difermentasi oleh bakteri asam laktat (Bujalance et al., 2006; Sathyanarayanan et al., 2011).

\section{Uji Katalase}

Berdasarkan uji katalase yang telah dilakukan, didapatkan hasil bahwa isolat 18A mempunyai sifat katalase negatif. Hal ini ditunjukkan dengan tidak terbentuknya gelembung gas pada preparat. Hasil ini menunjukkan bahwa isolat yang telah direkultur merupakan bakteri asam laktat. Bakteri asam laktat menunjukkan hasil negatif pada uji katalase karena bakteri ini tidak memiliki enzim katalase, sehingga tidak dapat memecah $\mathrm{H}_{2} \mathrm{O}_{2}$ menjadi $\mathrm{H}_{2} \mathrm{O}$ dan $\mathrm{O}_{2}$ (Konig dan Frohlich, 2009). Hasil ini sesuai dengan penelitian terdahulu yang mengidentifikasi bahwa bakteri asam laktat yang diisolasi dari susu kedelai (Yusmarini et al., 2009), makanan hasil fermentasi (Bukola et al., 2008), dan cairan rumen sapi bali (Suardana et al., 2007) bersifat katalase negatif.

\section{Pewarnaan Gram}

Uji pewarnaan Gram menunjukkan bahwa isolat $18 \mathrm{~A}$ tergolong sebagai bakteri Gram postif dan mempunyai bentuk bulat (kokus) berantai (Gambar 1). Menurut Surono (2004), bakteri asam laktat mempunyai variasi karakteristik yang cukup besar, namun salah satu sifat yang mutlak dimiliki oleh bakteri asam laktat adalah sebagai bakteri Gram positif.

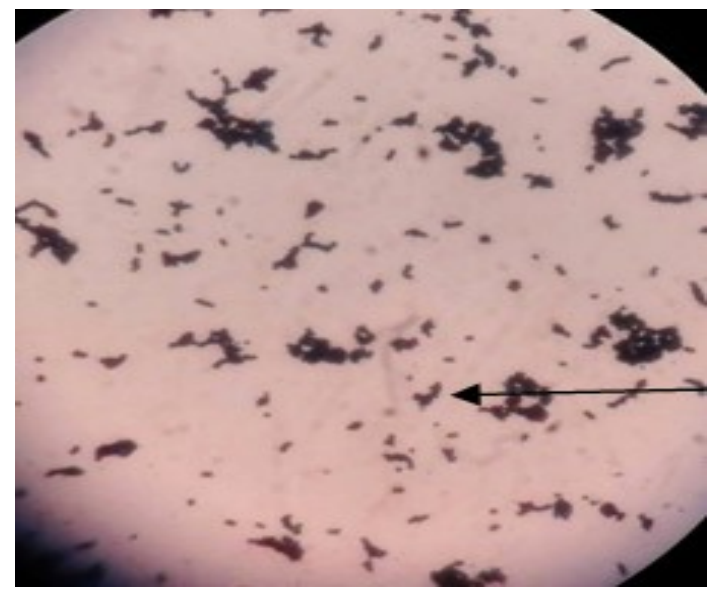

Gambar 1. Hasil Pewarnaan Gram Isolat 18A yang Dilihat di Bawah Mikroskop dengan Perbesaran 1000 kali. 
Pernyataan ini didukung oleh hasil penilitian yang menyebutkan bahwa, bakteri asam laktat yang diisolasi dari youghurt (Nuryady et al., 2013), susu kedelai (Yusmarini et al, 2009), makanan hasil fermentasi (Bukola et al., 2008), dan cairan rumen sapi bali (Suardana et al., 2007) merupakan bakteri Gram positif. Bakteri Gram positif akan memberikan warna ungu ketika diberi cat Gram. Warna ungu tersebut terjadi karena dinding sel bakteri mengikat cat kristal violet yang diperkuat oleh iodine dan kristal violet tersebut tidak akan hilang pada waktu diberi cat peluntur (Suryani, 2010).

\section{Uji Identifikasi Isolat 18A \\ Uji Produksi Gas CO2}

Berdasarkan uji produksi gas $\mathrm{CO}_{2}$ yang telah dilakukan, didapatkan hasil bahwa isolat $18 \mathrm{~A}$ tidak mampu menghasilkan gas $\mathrm{CO}_{2}$. Hal ini ditunjukkan dengan tidak terbentuknya gelembung gas pada media MRS broth yang berisi isolat 18A. Sehingga bakteri asam laktat isolat 18A digolongkan sebagai bakteri homofermentatif. Bakteri homofermentatif tidak mampu menghasilkan gas $\mathrm{CO}_{2}$, karena tidak memiliki enzim piruvat oksidase yang mampu mengkonversi piruvat menjadi $\mathrm{CO}_{2}$ dan asetil fosfat dengan diikuti pembentukan $\mathrm{H}_{2} \mathrm{O}_{2}$ (Surono, 2004). Untuk pengembangan sebagai probiotik, bakteri asam laktat yang memiliki sifat homofermentatif lebih disukai karena tidak menghasilkan $\mathrm{CO}_{2}$ yang dapat menyebabkan perut menjadi kembung (Swartz, 2013).

\section{Uji Pertumbuhan pada Suhu $10^{\circ} \mathrm{C}$}

Berdasarkan uji pertumbuhan pada suhu $10^{\circ} \mathrm{C}$ yang telah dilakukan, didapatkan hasil bahwa isolat 18A mampu tumbuh pada media MRS broth yang diinkubasi pada suhu $10^{\circ} \mathrm{C}$. Pertumbuhan tersebut ditunjukkan dengan kekeruhan pada media, didukung dengan hasil pemeriksaan menggunakan spectrophotometers yang menunjukkan nilai optical density sebesar 0,530. Hasil pertumbuhan tersebut lebih rendah dibandingkan dengan kontrol. Isolat bakteri yang diinkubasi pada suhu $37^{\circ} \mathrm{C}$ (kontrol) menunjukkan kekeruhan media yang tinggi dengan nilai optical density sebesar 1,073 .

\section{Uji Pertumbuhan pada pH 9,6}

Berdasarkan uji pertumbuhan pada $\mathrm{pH}$ 9,6 yang telah dilakukan, didapatkan hasil bahwa isolat 18A tidak tumbuh pada media MRS broth yang diinkubasi pada pH 9,6. Hal ini ditunjukkan dengan tidak nampak adanya kekeruhan pada media, didukung dengan hasil pemeriksaan menggunakan spectrophotometers yang menunjukkan nilai optical density sebesar 0,255. Hal ini didukung oleh beberapa penelitian terdahulu yang menyebutkan bahwa bakteri dikatakan tumbuh pada suatu media jika memiliki nilai optical density lebih dari 0,4 (Campbell, 2011). Jika dibandingkan dengan kontrol, yakni isolat yang ditumbuhkan pada MRS broth dengan $\mathrm{pH}$ 6,2, menunjukkan bahwa isolat kontrol dapat tumbuh dengan baik. Isolat bakteri yang diinkubasi pada MRS broth dengan pH 6,2 menunjukkan kekeruhan media yang cukup tinggi dengan nilai optical density sebesar 1,112.

\section{Analisis Genus dari Isolat 18A}

Berdasarkan hasil penelitian diatas yang kemudian dinilai berdasarkan metode Holzapfel dan Shilinger (1992) dalam Widodo (2003) meliputi uji produksi gas $\mathrm{CO}_{2}$, pertumbuhan pada suhu $10^{\circ} \mathrm{C}$, dan pertumbuhan pada $\mathrm{pH}$ 9,6 didapatkan hasil bahwa isolat $18 \mathrm{~A}$ merupakan bakteri genus Lactococcus.

\section{Pembahasan}

Hasil penelitian ini didukung dengan beberapa penelitian sebelumnya, yang menyebutkan bahwa Lactococcus $s p$ merupakan bakteri dengan karakteristik homofermentatif, dapat tumbuh pada suhu $10-40^{\circ} \mathrm{C}$, dan tidak tumbuh pada suasana basa dengan pH 9,6 (Mourad et al., 2004). Bakteri Lactococcus sp termasuk golongan bakteri homofermentatif tidak memiliki enzim piruvat oksidase yang berperan dalam konversi piruvat menjadi 
$\mathrm{CO}_{2}$ dan asetil fosfat. Ini ditandai dengan hasil negatif pada uji oksidase (Surono, 2004).

Bakteri Lactococcus sp, seperti kebanyakan bakteri asam laktat lainnya, merupakan bakteri mesofilik yang tumbuh optimum pada suhu $20-30^{\circ} \mathrm{C}$. Produksi asam umumnya menurun atau bahkan berhenti sama sekali pada saat bakteri diinkubasi pada suhu dibawah $20^{\circ} \mathrm{C}$, namun pertumbuhan bakteri yang memiliki rentang $10-42^{\circ} \mathrm{C}$ tidak dihambat (Ahmed et al., 2006). Suhu tumbuh optimum Lactococcus sp adalah $30^{\circ} \mathrm{C}$ dan dapat tumbuh pada suhu $10^{\circ} \mathrm{C}$, namun tidak tumbuh pada suhu $45^{\circ} \mathrm{C}$ (Batt, 1999). Semakin rendah suhu inkubasi dari Lactococcus sp akan mengakibatkan perubahan metabolisme khususnya aktivitas glikolisis yang berakibat pada menurunnya aktivitas pertumbuhan jika dibandingkan pada suhu optimum (Wouters et al., 2000).

Lactococcus sp merupakan bakteri yang dapat bertahan hidup hingga $\mathrm{pH} 4,0$, namun $\mathrm{pH}$ optimum untuk pertumbuhan Lactococcus $s p$ adalah pada lingkungan dengan $\mathrm{pH}$ antara 4,5 dan 6,5. Kemampuan adaptasi yang tinggi dari Lactococcus sp dikarenakan respon terhadap stress $\mathrm{pH}$ yang cepat terhadap regulasi sintesis protein untuk bertahan pada pH rendah (Rallu et al., 1996; Andersen et al., 2009). Adaptasi ini umumnya meliputi perubahan aktivitas metabolisme (Sanchez et al., 2008). Namun penelitian mendapati bahwa Lactococcus sp tidak dapat tumbuh pada $\mathrm{pH}$ tinggi (Mourad et al., 2004). Penelitian menunjukkan bahwa peningkatan $\mathrm{pH}$ medium kultur Lactococcus sp dari pH 6,5 menjadi 9,25 menyebabkan penurunan rasio jumlah bakteri terhadap produksi laktat (Hofvendahl et al., 1999; Klinkenberg et al., 2001).

\section{Konfirmasi bakteri asam laktat hasil identifikasi dengan uji Kit API 50 CHL.}

Isolat selanjutnya diidentifikasi secara biokimiawi berdasarkan kemampuannya memfermentasi karbohidrat menggunkan kit API 50 CHL. Uji fermentasi dengan menggunakan perangkat kit API 50 CHL dengan waktu inkubasi selama 24 jam, dan penelitian menunjukkan bahwa hasil pengamatan uji API $50 \mathrm{CH}$ setelah waktu inkubasi 24 jam telah memberikan data yang valid (Awan et al., 2005). Hasil uji API $50 \mathrm{CH}$ menunjukkan bahwa isolat 18A mampu mendegradasi 15 komponen gula, yaitu komponen gula no: $5,10,11$, $12,13,22,24,25,26,27,28,29,30,31$, dan 39 (Gambar 2). Komponen gula yang didegradasi oleh isolat $18 \mathrm{~A}$ antara lain DRibose, D-Galactose, D-Glucose, DFructose, D-Mannose, NAcetylGlucosamine, Arbutin, Esculin feric citrate, Salicin, D-Celiobiose, Maltose, DLactose, D-Melibiose, D-Saccharose, Gentiobiose.

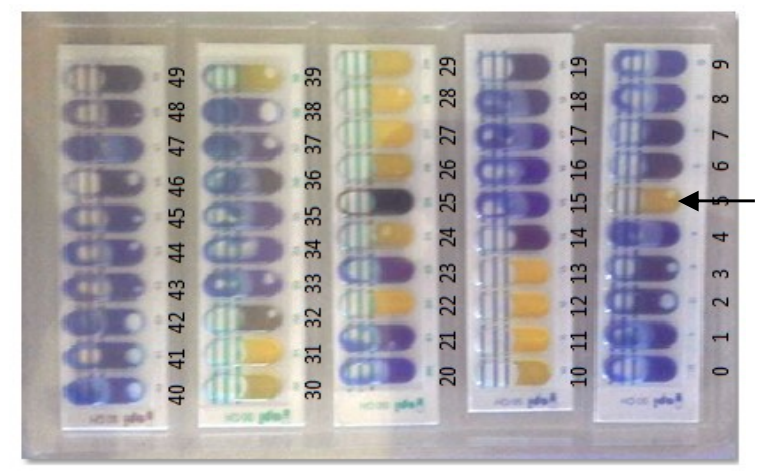

Gambar 2. Hasil uji kit API 50 CHL inkubasi 24 jam. Tanda panah $(\rightarrow)$ menunjukkan reaksi positif isolat $18 \mathrm{~A}$ pada gula No.5 (D-Ribose).

Ket: $(+)$ : dapat memfermentasi;

(-) : tidak dapat memfermentasi

Berdasarkan hasil identifikasi spesies dengan menggunakan perangkat kit API 50 CHL medium versi 5.1 (biomerieoux) yang dilanjutkan dengan pengolahan dan analisis menggunakan software APIWEB, didapatkan bahwa isolat $18 \mathrm{~A}$ adalah Lactococcus lactis ssp lactis 1, dengan nilai identifikasi 73,5\%. Penelitian terdahulu juga telah berhasil mengisolasi bakteri Lactococcus lactis ssp lactis 1 dari cairan rumen sapi bali (Suardana et al., 2007), saluran cerna ikan (Itoi et al., 
2009), bir komersial (Togo et al., 2002), dan susu (Doutoum et al., 2013) yang dikonfirmasi dengan kit API 50 CHL.

Jika diamati lebih lanjut, nilai identifikasi 73,5\% dari hasil penelitian ini cukup rendah jika dibandingkan dengan penelitian-penelitian sebelumnya yang umumnya mendapati nilai identitas lebih dari $90 \%$, bahkan mencapai 100\% (Barbu, 2008). Namun nilai identitas $73,5 \%$ masih dapat dikatakan valid, yang didukung dengan hasil penelitian yang menyatakan nilai identitas $70 \%$ masih dapat digunakan dalam penentuan spesies bakteri asam laktat (Nigatu, 2000; Mlalazi et al., 2011).

\section{SIMPULAN DAN SARAN}

\section{Simpulan}

Berdasarkan hasil identifikasi secara konvensional diketahui isolat $18 \mathrm{~A}$, sebagai bakteri genus Lactococcus. Uji konfirmasi menggunakan Kit API 50 CHL terhadap isolat 18A, didapatkan bakteri Lactococcus Lactis ssp lactis 1.

\section{Saran}

Perlu dilakukan uji lanjutan untuk mengeksplorasi potensi bakteri asam laktat isolat $18 \mathrm{~A}$ sebagai kandidat probiotik dan biopreservatif.

\section{UCAPAN TERIMA KASIH}

Penulis mengucapkan terima kasih kepada pusat penilitian Universitas Udayana yang telah mendanai penelitian ini melalui proyek penelitian hibah 2014. (Hibah no 103.56/UN.14.2/PNL.01.03.00/2014).

\section{DAFTAR PUSTAKA}

Ahmed T, Kanwal R, Ayub N. 2006. Influence of Temperature on Growth Pattern of Lactococcus lactis, Streptococcus cremoris and Lactobacillus acidophilus Isolated from Camel Milk. Biotechnol. 5: 481488.

Amiza MA, Zakiah J, Khim Ng L, Lay KW. (2006). Fermentation of
DOI: 10.24843/bulvet.2018.10.1.1

tempoyak using isolated tempoyak culture Res. J. of Microbiol.1: 243-254. Andersen AZ, Carvalho AL, Neves AR, Santos H, Kummer U, Olsen LF. 2009. The metabolic $\mathrm{pH}$ response in Lactococcus lactis: An integrative experimental and modelling approach. Computational Biol. and Chem. 33(1): 71-83.

Awan MB, Ahmed MM, Bari A, Saad AM. 2005. Biocehmical characterization of the Aeormonas species isolated from food and anvironment. Pak. J. Physiol. 1(1-2).

Barbu V. 2008. Phenotypical characterization of several lactic acid bacteria strains isolated from wheat's epiphyte microbiota. Roumania Biotech. Let. 13(6): 4074-4085.

Batt CA. 1999. Lactooccus Department of Food Science. Cornell University, USA.

Bromberg R, Moreno I, Zaganini C.L, Delboni R.R, and Oliveira J. 2004. Isolation of Bacteriocin-producing lactic acid bacteria from meat and meat products and its spectrum of inhibitory activity. Braz. J. of Micrbiol. 35: 137144.

Bujalance C, Jiménez-Valera M, Moreno E, Ruiz-Bravo A. 2006. A selective differential medium for Lactobacillus plantaru. J. Microbiol. Met. 66: 572575.

Bukola C. Adebayo- tayo, Onilude AA. 2008. Screening of Lactic Acid Bacteria Strains Isolated from Some Nigerian Fermented Foods for EPS Production. World App. Sci. J. 4 (5): 741-747.

Campbell J. 2011. High-throughput assessment of bacterial growth inhibition by optical density measurements. Curr. Protoc. Chem. Biol. 3(3): 100-115.

de Man JC., Rogosa M., Sharpe M. E.1960. A medium for the cultivation of lactobacilli. J. Appl. Bacteriol. 23: 130-135. 
Doutoum AA, Tidjani A, Sylla

KSB, Tidjani SMT, Alambedji RB, Balde M, Abdelaziz AI, Seydi MG, Toguebaye BS. 2013. Identification of lactic acid bacteria in traditional curd in the Sudanian zone of Chad. Int. Res. J. of Microbiol. 4(5): 119-124.

Hofvendahl B, van Niel EWJ, HahnHägerdal B. 1999. Effect of temperature and $\mathrm{pH}$ on growth and product formation of Lactococcus lactis ssp. lactis ATCC 19435 growing on maltose. App. Microbiol. and Biotechnol. 51(5): 669-672.

Itoi S, Yuasa K, Washio S, Abe T, Ikuno $\mathrm{E}$, Sugita $\mathrm{H}$. Phenotypic variation in Lactococcus lactis subsp. lactis isolates derived from intestinal tracts of marine and freshwater fish. J. Appl. Microbiol. 107(3): 867-874.

Klinkenberg G, Lystad KQ, Levine DW, Dyrset N. 2001. pH-controlled cell release and biomass distribution of alginate-immobilized Lactococcus lactis subsp. Lactis. J. App. Microbiol. 91(4): 705-714.

Konig and Frohlich. 2009. Lactic Acid Bacteria. In : H. König et al. (eds.), Biology of Microorganisms on Grapes, in Must and in Wine, 3. SpringerVerlag Berlin Heidelberg.

Leisner JJ, Vancanneyt M, Rusul G, Pot B, Lefebvre K, Fresi A, Tee LK. (2001). Identification of lactic acid bacteria constituting the predominating microflora in acid-fermented condiment (tempoyak) popularin Malaysia. Int. J. of Food Microbiol. 63: 149-157.

Leroy F, Vuyst LD. 2001. Growth of the Bacteriocin-ProducingLactobacillus sakei Strain CTC 494 in MRS Broth Is Strongly Reduced Due to Nutrient Exhaustion: a Nutrient Depletion Model for the Growth of Lactic Acid Bacteria. Appl. Environ. Microbiol. 67(10): 4407-4413.

Lidawati, SA, Suardana, IW. 2014. Isolasi dan Uji Potensi Bakteriosin dari
Bakteri Asam Laktat Hasil Isolasi dari Kolo Sapi Bali sebagai Kandidat Unggul Biopreservatif. Laporan Akhir Penelitian Hibah Bersaing. Fakultas Peternakan, Universitas Udayana, Denpasar.

Ljungh A, Wadström T. 2006. Lactic acid bacteria as probiotics. Curr. Issues. Intest. Microbiol. 7(2): 73-89.

Mlalazi M., Angela R. Winslow, Junia Jean-Gilles Beaubrun, Broderick E.E. 2011. Occurrence of Pediocin PA1/AcH-Like Bacteriocin in Native Non-starter Lactobacillus casei, Lactobacillus paracasei and Lactobacillus rhamnosus from retail Cheddar cheese. Int. J. Food Safety. 13: 325-331.

Mourad K, Halima Z, Nour-Eddine K. 2004. Isolation of lactic acid bacteria for its possible use in the fermentation of green Algerian olives. Grasas. $Y$. Acites. 55(4): 385-393.

Nigatu A. 2000. Evaluation of numerical analyses of RAPD and API $50 \mathrm{CH}$ patterns to differentiate Lactobacillus plantarum, Lact.fermentum, Lact. rhamnosus, Lact. sake, Lact. parabuchneri, Lact. gallinarum, Lact. casei, Weissella minor and related taxa isolated from kocho and tef. J. Appl. Microbiol. 89(6): 969-78.

Nurhayati, Jenie BSL, Kusumaningrum HD, Widowati S. 2011. Identifikasi Fenotipik dan Genotipik Bakteri Asam Laktat asal Fermentasi Spontan Pisang var. Agung Semeru (Musa paradisiacal formatypica). J. Ilmu Dasar. 12(2): 210-225.

Pratita MYE, Putra S R. 2012. Isolasi Dan Identifikasi Bakteri Termofilik Dari Sumber Mata Air Panas Di Songgoriti Setelah Dua Hari Inkubasi. J. Teknik Pomits. 1(1): 1-5.

Rallu F, Gruss A, Maguin E. Lactococcus lactis and stress. Antonie Van Leeuwenhoek. 70(2-4): 243-51.

Sánchez C, Neves AR, Cavalheiro J, dos Santos MM, García-Quintáns N, López 
P, and Santos H. 2008. Contribution of Citrate Metabolism to the Growth of Lactococcus lactis CRL264 at Low pH. Appl. Environ. Microbiol. 74(4): 1136-1144.

Saptayanti, NN., Suatha, IK., dan Sampurna, IP. 2015. Hubungan Antara Dimensi Panjang Induk Dengan Pedet Pada Sapi Bali. Bul. Vet. Udayana. 7(2) :129-136.

Sari SR, Suartha, IN, Batan, IW. 2016. Status Persen Pedet Sapi bali. Bul.Vet. Udayana. 8(1): 36-43.

Sathyanarayanan J, Kunthala J, Gurumurthy K. 2011. Optimization of MRS media components using response surface methodology for the riboflavin production by Lactobacillus fermentum isolated from yoghurt sample. Int. Food Res. J. 18: 149-158

Suardana IW, Suarsana IN, Sujaya IN, Wiryawan KG. 2007. Isolasi Dan Identifikasi Bakteri Asam Laktat Dari Cairan Rumen Sapi Bali Sebagai Kandidat Biopreservatif. J. Veteriner. 8(4) :155-159.

Suarsana, IN. 2011. Karakterisasi Fisikokimia Bakteriosin Yang Diekstrak Dari Yoghurt. Bul. Vet. Udayana. 3(1):1-8.

Surono IS. 2004. Probiotik Susu Fermentasi Dan Kesehatan. Penerbit YAPPMI. Jakarta.

Suryani Y, Astuti, Oktavia B, Umniyati S. 2010. Isolasi Dan Karakterisasi Bakteri Asam Laktat Dari Limbah Kotoran Ayam Sebagai Agensi Probiotik Dan Enzim Kolesterol
Reduktase. Prosiding Seminar Nasional Biologi. Yogyakarta.

Togo CA, Feresu SB, Mutukumira AN. 2002. Identification of Lactic Acid Bacteria isolated from Opaque beer (Chibuku) for potential use as a starter culture. J. Food Tech. in Africa 7(3): 93-97.

Vijayabaskar P, Somasundaram ST. 2008. Isolation of Bacteriocin Producing Lactic Acid Bacteria from Fish Gut and Probiotic Activity Against Common Fresh Water Fish Pathogen Aeromonas hydrophila. Biotechnol. 7: 124-128.

Widiasih, T. 2008. Aktivitas Substrat Antimikroba Bakteri Asam Laktat Yang Diisolasi Dari Daging Sapi Terhadap Bakteri Patogen dan Konsentrasi Minimum Penghambatnya. Skripsi. Fakultas Peternakan, Institut Pertanian Bogor, Bogor.

Widodo. 2003. Bioteknologi Industri Susu. 1. Lacticia Press. Yogyakarta

Wouters JA, Kamphuis HH, Hugenholtz J, Kuipers OP, de Vos WM, Abee T. 2000. Changes in glycolytic activity of Lactococcus lactis induced by low temperature. Appl. Environ. Microbiol. 66(9): 3686-91.

Yang E, Fan L, Jiang Y, Doucette C, Fillmore S. 2012. Antimicrobial activity of bacteriocin-producing lactic acid bacteria isolated from cheeses and yogurts. AMB. Express. 2(1): 48.

Zacharof MP, Lovitt R.W. 2012. Bacteriocins Produced by Lactic Acid Bacteria a Review Article. APCBEE. Procedia. 2: 50-56. 